\title{
Assessing the Knowledge, Attitude and Practices of Hikers on Drinking Surface Water while Hiking
}

Leanne Perrich ${ }^{1}$, Helen Heacock ${ }^{2}$

1 Lead Author, B. Tech Student, School of Health Sciences, British Columbia Institute of Technology, 3700 Willingdon Ave,

Burnaby, BC V5G $3 \mathrm{H} 2$

2 Supervisor, School of Health Sciences, British Columbia Institute of Technology, 3700 Willingdon Ave, Burnaby, BC V5G 3H2

\section{Abstract}

Background: Hiking is a popular outdoor activity among British Columbians. Within this group of hikers there is bound to be a wide range of knowledge for what is 'right' and 'wrong' in terms of health and safety practices while hiking. Assessing hiker's knowledge, attitude and practices regarding drinking water while hiking can help identify whether education for safe drinking water for hikers is needed to aid in the prevention of waterborne illnesses. In addition, potential barriers to hikers treating their water in the wilderness can be determined, with the goal of being able to reduce these barriers in the future.

Methods: The survey was created using Survey Monkey and distributed as an online selfadministered survey through Facebook and email. The survey contained 18 questions which consisted of demographic and knowledge, attitude, and practice (KAP) questions regarding drinking surface water while hiking. Chi-square statistical tests were used to analyze the data.

Results: Of the 328 participants; $72.7 \%$ were female, $26.1 \%$ male, $0.6 \%$ other and $0.6 \%$ preferred not to answer. The distribution of age groups was as follows: $31.4 \%$ were $19-30$ years old, $27.6 \%$ were $31-45$ years old, $26.4 \%$ were $46-60$ years old, $14.0 \%$ were $61+$ years old, and $0.6 \%$ preferred not to answer. This study found that the more outdoor knowledge hikers had, the more often they treated surface water used for drinking water $(P=0.000)$, that hiker's attitude on how risky they thought drinking untreated surface water was affected how often they treated drinking water from surface water sources $(P=0.000)$. The more advanced hikers had more outdoor knowledge $(P=0.001)$, younger hikers thought that drinking untreated surface water was less risky $(P=0.025)$, post-secondary education did not determine how much outdoor knowledge hikers had $(P=0.088)$ and males treated their water less often than females $(P=0.014)$.

Conclusion: This study identified a need for accessible outdoor education with respect to safe drinking water. This education can help hikers make informed decisions to safeguard their health while hiking. This information can be distributed by outdoor organizations, government organizations, high school health education classes, and integrated into outdoor advertisements.

Keywords: hiking, hiker, waterborne illness, giardia, water treatment, drinking water, surface water

\section{Introduction}

Hiking is a long-loved activity for the

people of British Columbia. Being surrounded by mountains makes it a perfect location to explore the outdoors, but not everyone hikes so why is this a public health issue? In 2016, almost 70\% of Canadians participated in outdoor or wilderness 
activities and $44 \%$ hiked or backpacked (Statistics Canada, 2018). Among these hikers there is bound to be a wide range of knowledge for what is 'right' and 'wrong' while out hiking. In the mountains where the human visitor levels are relatively low, surface water sources such as streams can still be contaminated with bacteria, viruses and parasites that can result in waterborne illnesses (Centers for Disease Control, 2018). Symptoms of waterborne illness include diarrhea, stomach cramps, nausea, vomiting and/or fever (HealthLink, 2019). Severe complications and even death can occur in the sensitive population. (HealthLink, 2019). Therefore, assessing hiker's knowledge, attitude and practice regarding drinking water while hiking can help identify whether education for safe drinking water for hikers is needed. This could lead to the prevention of waterborne illnesses in addition to the identification of barriers to applying their drinking water knowledge.

\section{Literature Review}

Waterborne Illness

Waterborne illness is an important public health issue. Although preventable, it is still common (Government of Canada, 2013). A waterborne illness is contracted by consuming contaminated water and is most often caused by bacteria, parasites or viruses (Government of Canada, 2013).
Contamination of water by human or animal feces can introduce pathogens such as $\mathrm{E}$. coli, Campylobacter, Salmonella, Giardia and Cryptosporidium. These pathogens can cause waterborne illnesses but are also associated with foodborne illnesses or are spread person to person via the fecal-oral route, therefore, it is hard to determine the exact cause of an illness.

Giardia is the most common intestinal parasite in both the USA and Canada and hikers are among the most frequently affected groups in developed countries (Government of Canada, 2012). Giardiasis is often known as beaver fever in the general population; this common name occurred after an outbreak arose in Banff National Park among a group of hikers that had become ill after drinking water from a stream that was contaminated with Giardia from beavers (Government of Ontario, 2015).

The incidence of waterborne illness in Canada is hard to determine as Canada does not currently have a surveillance system for waterborne illnesses (National Collaborating Centres for Public Health, 2011). However, Giardia and Cryptosporidium are on both BC's and Canada's reportable disease list and they are most often spread through contaminated water (HealthLinkBC, 2016 \& HealthLinkBC, 2018).

\section{Water Treatment Legislation}


Most Canadians do not have to worry about the safety of drinking water from their taps on a day-to-day basis, and this can largely be attributed to the multi-barrier approach to protect drinking water and the laws that govern drinking water. The Drinking Water Protection Act and Regulation is an integral part of the multi-barrier approach. The Drinking Water Protection Act and Regulation sets out the standards for water treatment, and water testing including the parameters to which they must measure and how often.

\section{Water Treatment}

Improvement of drinking water treatment is one of the top public health achievements of the 20th century (Ericsson, Steffen, \& Backer, 2002). The water treatment systems can range from simple and inexpensive to complex and worth millions of dollars based on the water source, size and budget of the organization building the system.

Water is a necessity while doing vigorous activity and no one should be without it. There could be a few reasons a hiker is in a situation where surface water is their only water source, such as running out of water sooner than planned or initially planning to use the surface water as a water source for a multi-day hike. The primary reason to treat water in the backcountry is to kill pathogens usually introduced by human or animal feces (Ericsson, Steffen, \& Backer, 2002). Fortunately, there have been technologies engineered to easily fit into a hiking backpack that adequately treats water. These methods include filters, chemical tablets or powder, Ultraviolet (UV) light or to simply boil water for at least 1 minute (Centers for Disease Control, 2013). Some methods are more effective than others, for example filters may not filter out all viruses and disinfection can vary in effectiveness for Cryptosporidium and Giardia cysts, therefore, a combination of these two methods would be the most protective (Ericsson, Steffen, \& Backer, 2002).

$\underline{\text { Knowledge, Attitude and Practice Surveys }}$ Knowledge, attitude and practices (KAP) surveys can present both qualitative and quantitative data that can help determine what is known, the opinion, and what is ultimately done, concerning a certain issue in a specific setting (Unite for Sight, 2015 \& USAID, 2011). KAP surveys also aim to discover any misunderstandings on the subject or possible barriers to the desired behaviour. The results from KAP surveys can be used as support for increased education programs, initiatives that could eliminate barriers to the desired behaviour and can also be used as a baseline for an assessment for the effectiveness of programs or initiatives. (USAID, 2011) 


\section{Previous Research Studies}

The number of people participating in outdoor activities, as well as the number of days people spend hiking are projected to at least double by 2050 (Forrester \& Holstege, 2009). With the increasing number of people in the backcountry, there is a need to educate them how to be safe while hiking and exploring the outdoors.

Many of the studies conducted related to hiking and waterborne illnesses focus on diarrhea as an outcome or look solely at Giardia. Adam et al., (2016) analyzed Giardia outbreak data between 1971-2011 and found that almost $75 \%$ of outbreaks were waterborne. However, according to Reses et al., (2018) over $99 \%$ of Giardia cases are sporadic (not associated with an outbreak), therefore most Giardia cases were not included or analyzed in Adam's et al. data set. Contracting Giardia while hiking would likely be a sporadic case as it would be a limited number of people drinking the water. Only a few case-control studies have been carried out regarding risk factors for sporadic cases, these being published in 1993 or earlier (Reses et al., 2018). With those studies being conducted over 25 years ago, many contributing factors have changed since then, therefore, these findings may no longer be applicable.

According to Reses et al. (2018) drinking water from a river, lake, stream, or spring resulted in a statistically significant increase for contracting giardiasis. This is similar to Boulware, Forgey, \& Martin's (2003) findings that showed a higher risk among long distance backpackers of experiencing diarrhea if an individual drank untreated surface water, as diarrhea is a common symptom of a waterborne illness. Spano, Hile, Jain \& Stalcup (2018) compared Boulware's et al. data on injury and illness among hikers on the Appalachian Trail to their own data regarding injury and illness of hikers on the John Muir Trail in the Sierra Nevada (USA). They suggested that the higher incidence of diarrhea in hikers on the Appalachian Trail was due to a higher total coliform in the backpackers' site of water, which can indicate contamination, and a lower rate of compliance of water treatment (Spano, Hile, Jain \& Stalcup, 2018). A study somewhat contradictory to these findings was a meta-analysis study conducted by Welch that suggested that although Giardiasis was more common in campers and backcountry users that it may not be due to drinking surface water but due to reduced personal hygiene (2000). His study also is not comparable to the previous studies as it is almost 20 years old and looks exclusively at Giardia, excluding the other enteric pathogens that can cause waterborne illnesses. A study done on long distance backpackers by Meyer, Costantino \& Spano (2017) found that the incidence of diarrhea 
was $11-56 \%$; however, there was no statistical significance between water filtration/treatment and diarrhea. There also was no significant association in the incidence of diarrhea and age, gender or experience of hikers. This finding could lead to the question of whether they are using the correct type of treatment and/or are they using the water treatment properly. Alternatively, it may coincide with Welch's theory of poor hygiene leading to diarrhea or Giardia infections.

Kortenkamp, Moore, Sheridan \& Ahrens (2017) analyzed peer reviewed journals that discussed factors contributing to hiker's injury and illness and found that the number one factor was "to the hikers' lack of preparation, awareness, or knowledge". Recommendations included education; that the hikers educate themselves, and encouraging institutions to provide accessible and useful education opportunities (Kortenkamp et al., 2017).

\section{Purpose of the Study}

The purpose of this research project was to assess the knowledge, attitudes and practices of hikers with respect to drinking surface water. Whether knowledge translates into behaviour can be analyzed and the potential barriers for treating surface water used for drinking water while hiking can be identified. This could potentially lead to stakeholders such as public health organizations, outdoor organizations or companies with water treatment products initiating health promotion projects. These projects could target hikers to either educate themselves on safe drinking water practices and/or implement strategies to reduce potential barriers to hikers treating their water in the wilderness.

\section{Methods and Materials}

Materials

- This study used a laptop with internet access for distribution of the online survey, SurveyMonkey software (SurveyMonkey, 2020), Excel, NCSS 2019 for statistical analysis (NCSS Statistical Software, 2020) and a Facebook Account.

\section{Methods}

The survey was distributed as an online self-administered survey on the platform SurveyMonkey and was open for two weeks from January 12, 2020 - January 26 , 2020. The survey was posted on Facebook as a public post to ensure that anyone, with or without a Facebook account, was able to reach the survey (Facebook, 2020). The survey was also distributed by email to groups of interest. All methods of sharing the survey distributed the same online, self-administered survey.

The survey consisted of demographic, knowledge, attitude, and practice (KAP) questions regarding drinking surface water while hiking. Most of the 
questions were closed answer, however, there were two questions with multiple choice answers that were labelled as 'Other - please specify' and allowed the participant to give an answer that was not on the list. The knowledge-based questions had the option of selecting 'I don't know' in the attempt to avoid any guessing of the correct answers and resulting in an inaccurate knowledge categorization.

$\underline{\text { Inclusion }}$

Persons who were current residents of British Columbia and had hiked at least once in the past 3 years, could participate in the survey. The definition of hiking for the purpose of this study was: walking in natural environments for at least 1 hour, often with a gain in elevation.

\section{Ethics}

To ensure the ethics of this research study the methodology, cover letter, consent form and survey questions were sent to, and approved by, the BCIT Research Ethics Board before the survey was disseminated.

\section{Results}

Description of Data

Nominal data was collected which included demographics and practices. Ordinal data was also collected which included education level, knowledge level, level of the hiker, and attitude. The attitude of the participant was determined by how safe they perceived drinking untreated surface water from streams or rivers was. The level of the hiker was assessed using the length of hike they most often participated in; the longer the hike, the more advanced they were. The knowledge of the participant was categorized into one of three categories depending on the number of correct answers out of 10: low (0-4), moderate (5-7) or high (8-10).

\section{Descriptive Statistics}

Out of the 328 people who completed the survey, $72.67 \%$ were female, $26.13 \%$ male, $0.6 \%$ other and $0.6 \%$ preferred not to answer. The distribution of age groups was fairly evenly spread: $31.44 \%$ were $19-30$ years old, $27.54 \%$ were $31-45$ years old, $26.35 \%$ were $46-60$ years old, $14.07 \%$ were $61+$ years old and $0.6 \%$ preferred not to answer. The participants' location of residence was: $0.9 \%$ Northern BC, $41.99 \%$ Vancouver Island/Coast, 16.01\% Thompson Okanagan, 30.51\% Lower Mainland, 9.67\% Kootenays and $0.91 \%$ did not specify their current location of residence.

Out of the 326 calculated scores, $58.6 \%$ scored 'high', 34.4\% scored 'moderate', and $7.1 \%$ scored 'low' in drinking water knowledge. To assess the participants' attitude toward drinking untreated surface water the following question was asked 
"How do you feel about the following sentence: 'Drinking water directly from a stream or river is safe'. $1.8 \%$ strongly agreed, $12.8 \%$ agreed, $16.5 \%$ were neutral, $48.2 \%$ disagreed and $20.7 \%$ strongly disagreed. Participants were asked if they had ever drunk surface water while hiking and if the answer was yes, they proceeded to the next question that asked how often they treated the surface water. Participants answered: $51.2 \%$ all the time or had never drank surface water, $23.8 \%$ most of the time, $2.7 \%$ half of the time, $8.8 \%$ some of the time, $11.6 \%$ never, and $1.8 \%$ did not remember. Out of the 151 people who had drank surface water without treating it, the top 2 reasons were: they ran out of water and didn't have treatment with them (29.8\%) and they assessed the water to be safe (35.1\%) (Figure 1).

Figure 1: Reasons for Drinking Untreated Surface Water

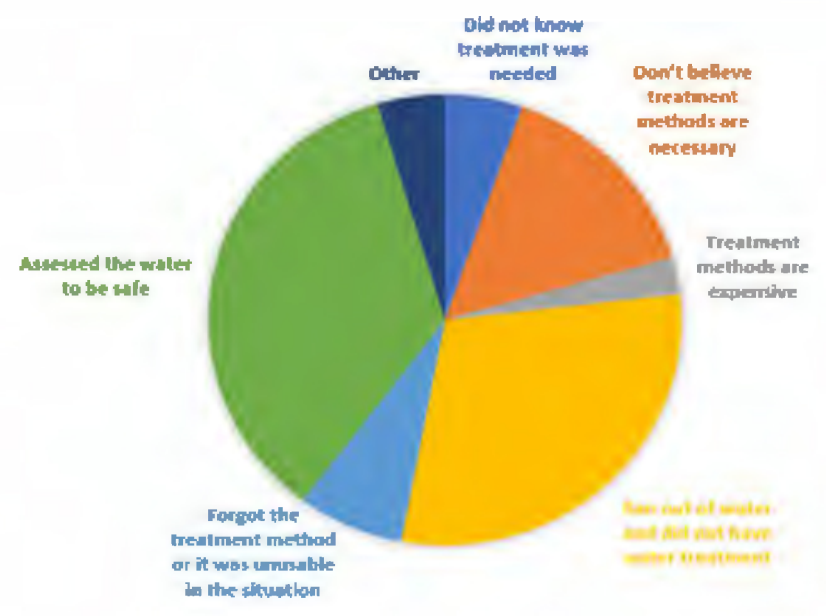

When asked about where the hikers learned about drinking water safety they picked all the options that applied to them and the top 3 responses were: learned from friends and family $(60.6 \%)$, from personal experience $(47.7 \%)$ and from advertisements (31.7\%) (Figure 2).

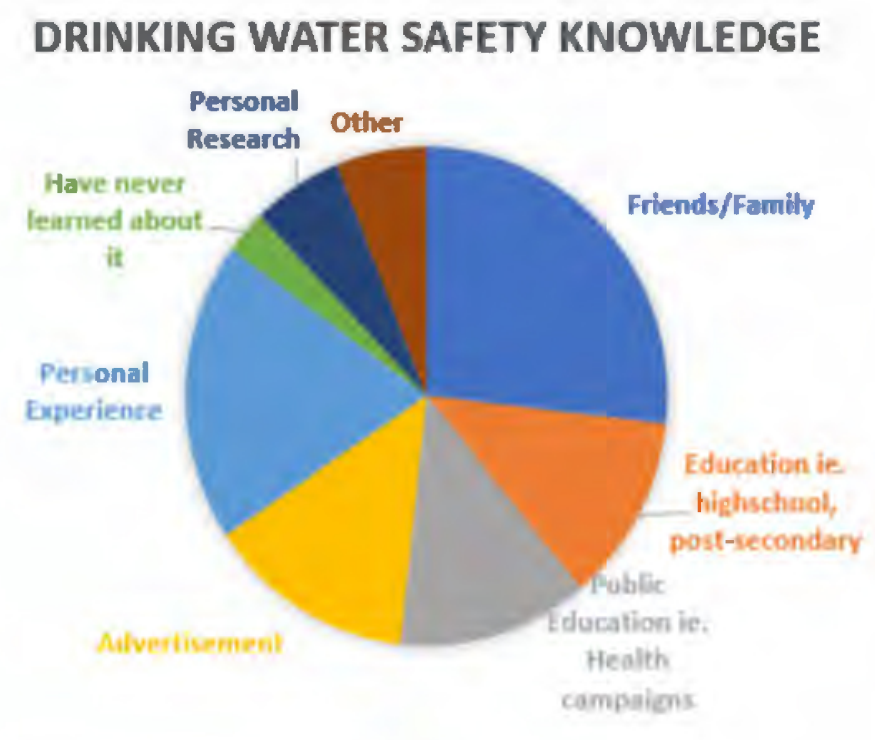

Figure 2: Sources of Drinking Water Knowledge

\section{Inferential Statistics}

Using the statistical software NCSS 2019 the two groups of nominal or ordinal data in each hypothesis were analyzed using a Chi-square test to compare frequencies among the data seen in Table 1 (Heacock \& Chen, 2019). 
Table 1: The Null and Alternative Hypotheses

\begin{tabular}{|c|c|c|}
\hline $\mathrm{Ha} \& \mathrm{Ho}$ & $\begin{array}{l}\mathrm{P} \text { - } \\
\text { value }\end{array}$ & Conclusion \\
\hline $\begin{array}{l}\text { Ho: there is no association between the } \\
\text { attitudes of hikers and their gender } \\
\text { Ha: there is an association between the } \\
\text { attitudes of hikers }\end{array}$ & 0.286 & $\begin{array}{l}\text { Do not reject Ho and conclude } \\
\text { there is no difference in attitudes } \\
\text { between males and females }\end{array}$ \\
\hline $\begin{array}{l}\text { Ho: there is no association between the } \\
\text { practices of hikers and their gender } \\
\text { Ha: there is an association between the } \\
\text { practices of hikers and their gender }\end{array}$ & 0.014 & $\begin{array}{l}\text { Reject Ho and conclude that the } \\
\text { practices between males and } \\
\text { females do differ. Males treated } \\
\text { their water less often. }\end{array}$ \\
\hline $\begin{array}{l}\text { Ho: there is no association between the } \\
\text { knowledge of hikers and their education level } \\
\text { Ha: there is an association between the } \\
\text { knowledge of hikers and their education level }\end{array}$ & 0.088 & $\begin{array}{l}\text { Do not reject Ho and conclude that } \\
\text { there is no association between } \\
\text { education level and their outdoor } \\
\text { knowledge level. }\end{array}$ \\
\hline $\begin{array}{l}\text { Ho: there is no association between the } \\
\text { attitude of hikers and their age group } \\
\text { Ha: there is an association between the } \\
\text { attitude of hikers and their age group }\end{array}$ & 0.025 & $\begin{array}{l}\text { Reject Ho and conclude there is a } \\
\text { difference in attitudes between age } \\
\text { groups. Younger hikers thought it } \\
\text { was safer than older hikers to drink } \\
\text { untreated surface water. }\end{array}$ \\
\hline $\begin{array}{l}\text { Ho: there is no association between the level } \\
\text { of hikers and their knowledge } \\
\text { Ha: there is an association between the level } \\
\text { of hikers and their knowledge level }\end{array}$ & 0.001 & $\begin{array}{l}\text { Reject Ho and conclude there is an } \\
\text { association between the knowledge } \\
\text { levels depending on the level of } \\
\text { hiker. The more advanced hikers } \\
\text { had more knowledge than the less } \\
\text { advanced hikers }\end{array}$ \\
\hline $\begin{array}{l}\text { Ho: there is no association between the } \\
\text { knowledge of hikers and their practices } \\
\text { Ha: there is an association between the } \\
\text { knowledge of hikers and their practices }\end{array}$ & 0.000 & $\begin{array}{l}\text { Reject Ho and conclude that there } \\
\text { is an association between } \\
\text { knowledge and hikers' practices. } \\
\text { The higher the knowledge level, the } \\
\text { more often they treated their water }\end{array}$ \\
\hline $\begin{array}{l}\text { Ho: there is no association between the } \\
\text { knowledge of hikers and their attitude } \\
\text { Ha: there is an association between the } \\
\text { knowledge of hikers and their attitude }\end{array}$ & 0.305 & $\begin{array}{l}\text { Do not reject Ho and conclude } \\
\text { there is no association between } \\
\text { knowledge and attitudes }\end{array}$ \\
\hline $\begin{array}{l}\text { Ho: there is no association between the } \\
\text { attitude of hikers and their practices } \\
\text { Ha: there is an association between the } \\
\text { attitude of hikers and their practices }\end{array}$ & 0.000 & $\begin{array}{l}\text { Reject Ho and conclude that the } \\
\text { attitudes and practices are } \\
\text { associated. The less safe they } \\
\text { thought untreated surface water } \\
\text { was, the more they treated the } \\
\text { water }\end{array}$ \\
\hline
\end{tabular}




\section{Discussion}

Knowledge and Education

From the statistical analyses it was found that the hikers who treated their water more often, perceived the untreated surface water to be riskier. The study also found that the more outdoor knowledge the participants had, the more often they treated their drinking water when it was from a surface water source. These results support Kortenkamp et al. (2017) study which recommended increased education to prevent injuries or illness to hikers in the outback, as treating surface water reduces the risk of experiencing diarrhea and Giardiasis (Boulware et al., 2003 \& Reses et al., 2018). Education could help the hikers be aware of their decisions, educate them on how to make smart decisions, and highlight the importance of being prepared for the unknown while hiking, all of which were factors that lead to injuries/illness according to the Kortenkamp et al. (2017) study. These factors also coincide with the given reasons for not treating surface water used for drinking water. The three main reasons were that they assessed the water to be safe, they do not believe treatment methods are necessary, and they ran out of water and did not have treatment methods available.

More evidence for the support of increased outdoor education was seen when looking at the qualitative data on where hikers learned about drinking water safety.
The top two answers being from their friends and family and from personal experience and/or research. This suggests that there is not a lot of outdoor education from schools, government organizations or outdoor organizations/stores, or the information is not well distributed. To be effective the outdoor education should be accessible and targeted towards all skill levels and ages. Easily accessible outdoor education would also be beneficial for the general public with the suggested increase in the amount of people participating in outdoor activities, as suggested by Forrester \& Holstege (2009). This would also be supported by the apparent lack of outdoor education in school (ie. Highschool and post-secondary) as the level of education a hiker has is not associated with the level of outdoor education.

\section{Demographics}

The analysis showed, with statistical significance, that the more advanced hikers had more outdoor knowledge, the younger hikers thought that drinking untreated surface water was less risky, and that males treated their water less often than females. This is somewhat contradictory to the study conducted by Meyer, Costantino \& Spano (2017) where there was no significant difference in the incidence of getting diarrhea and age, gender or experience of hikers. However, neither the current study or the 
Meyer, Costantino \& Spano (2017) study concluded that these factors resulted in diarrhea or the diarrhea was caused by the source of drinking water. In addition, the attitudes on the risk perception of drinking untreated surface water did not differ between males and females.

\section{Generalizability}

The results could be extrapolated to all residents of $\mathrm{BC}$, all ages, and both female and male genders since the participants had a relatively even distribution of demographics across all ages, from all across BC (excluding Northern BC) and both female and male genders.

\section{Limitations}

There are a few limitations to the selfadministered survey that was sent out via Facebook and an email list. To improve on the generalizability the study could have been distributed across multiple platforms as the survey was mainly accessed by Facebook users, and some email distribution. This method of recruiting participants may have been biased as the characteristics of the people not on Facebook or on the directed email list may have differed from the people who participated.

The criteria for a hike being one hour may not have been sufficient to capture 'true' hikes that would have hikers in the situation where they needed to drink water. By changing the inclusion criteria to people who participate in hikes two hours or more this could increase the validity of the survey.

\section{Knowledge Translation}

The statistical and descriptive data results could prompt stakeholders such as public health organizations, high schools, outdoor organizations or companies with water treatment products to put in place a health promotion initiative. The initiative should target all hikers to ensure that everyone receives the same and correct information on when and how to treat surface water. It could also encourage outdoor education for 'emergency preparedness' as $30 \%$ of the hikers that did not treat their water had been in a situation where they had run out of water. This education could take the form of a health promotion initiative or as an advertising tactic by a water treatment company as they can highlight their lightweight water treatment options so that hikers will always carry them, regardless of whether or not they plan on using them. Ensuring that the education given out is easily accessible, understandable and has realistic suggestions, regarding convenience and price, would be critical for the success of the health promotion initiative. 


\section{Future Research}

Future research projects could include:

- Conducting the same study, with changes that include distributing the survey across multiple platforms and changing the hiking criteria to at least 2 hours in length

- Comparing source of drinking water knowledge to knowledge level to assess efficacy of education

\section{Conclusion}

This research study found that the more outdoor knowledge hikers had, the more often they treated surface water used for drinking water. In addition, their attitude on how risky they thought drinking untreated surface water was affected how often they treated drinking water from surface water sources. The study also found that the more advanced hikers had more outdoor knowledge, the younger hikers thought that drinking untreated surface water was less risky, that post-secondary education did not determine how much outdoor knowledge hikers had and that males treated their water less often than females. These findings support the increased need for accessible and understandable outdoor education with respect to teaching about public health measures to avoid illness. Outdoor education can be distributed by outdoor organizations, government organizations in the form of health promotion programs, high school health education classes, and integrated into outdoor advertisements. Increasing education on how to safely spend time outdoors in the wilderness can help hikers make informed decisions to safeguard their health while hiking.

\section{Acknowledgements}

The lead author would like to thank Helen Heacock for her continued support and enthusiasm throughout the course of this study, as well as everyone who participated.

\section{Competing Interest}

The author declares that they have no competing interests.

\section{References}

Adam, E., Yoder, J., Gould, L., Hlavsa, M., Gargano, J. (2016). Giardiasis outbreaks in the United States, 19712011. Epidemiology and Infection, 144(13), 2790-2801

Boulware, D., Forgey, W., Martin, W. (2003). Medical Risks of Wilderness Hiking. The American Journal of Medicine, 114 (4), 288-293

Centers for Disease Control. (2013). Water Disinfection | Travelers Health.

Retrieved from https://wwwnc.cdc.gov/travel/page/water -disinfection

Centers for Disease Control. (2018). Camping, Hiking, Travel | Drinking Water. Retrieved from https://www.cdc.gov/healthywater/drinki ng/travel/index.html\#illness 
Ericsson, C. D., Steffen, R., \& Backer, H. (2002). Water Disinfection for International and Wilderness Travelers. Clinical Infectious Diseases, 34(3), 355-364

Facebook. (2020). Privacy Settings and Tools. Retrieved from https://www.facebook.com/settings?tab= privacy\&view

Forrester, J.D. \& Holstege, C.P. (2009). Injury and IIlness Encountered in Shenandoah National Park. Wilderness \& Environmental Medicine, 20(4), 318-326

Government of Canada. (2012). Pathogen Safety Data Sheets: Infectious Substances - Giardia lamblia. Retrieved from https://www.canada.ca/en/publichealth/services/laboratory-biosafetybiosecurity/pathogen-safety-datasheets-risk-assessment/giardialamblia.html

Government of Canada. (2013). The Chief Public Health Officer's Report on the State of Public Health in Canada, 2013: Infectious Disease-The Never-ending Threat. Retrieved from http://www.phacaspc.gc.ca/cphorsphcrespcacsp/2013/assets/pdf/2013eng.pdf

Government of Ontario. (2015). Giardiasis Disease and Conditions. Retrieved from http://www.health.gov.on.ca/en/public/pu blications/disease/giardiasis.aspx

Heacock, H., \& Chen, D. (2019). Module 4B Chi-Square Test [Powerpoint Slides]. Retrieved from https://learn.bcit.ca/d21/le/content/56988 4/viewContent/3947395/View

HealthLinkBC. (2016). Giardia Infection. Retrieved from https://www.healthlinkbc.ca/healthlinkbcfiles/giardia-infection
HealthLinkBC. (2018). Cryptosporidium Infection. Retrieved from https://www.healthlinkbc.ca/healthlinkbcfiles/cryptosporidium-infection

HealthLinkBC. (2019). Waterborne Infections in British Columbia. Retrieved from https://www.healthlinkbc.ca/healthlinkbcfiles/water-borne-infections

Kortenkamp, K., Moore, C., Sheridan D., Ahrens E. (2017). No Hiking Beyond this Point! Hiking Risk Prevention Recommendations in Peer-Reviewed Literature. Journal of Outdoor Recreation and Tourism, 20, 67-76

Meyer, D., Costantino, A., Spano, S. (2017). An Assessment of Diarrhea Among LongDistance Backpackers in the Sierra Nevada. Wilderness \& Environmental Medicine, 28 (1) pp: 4-9

National Collaborating Centres for Public Health. (2011). Water-borne Disease Outbreaks in Canadian Small Drinking Water Systems. Retrieved from http://www.ncceh.ca/sites/default/files/S DWS_Water-borne_EN.pdf

NCSS Statistical Software. (2020). Statistical Software | Data Analysis | Graphics Software. Retrieved from https://www.ncss.com/software/ncss/

Perrich, L. (2020). Assessing the Knowledge, Attitude and Practices of Hikers on Drinking Surface Water while Hiking. BCIT Environmental Health Journal

Spano, S.J., Hile, A.G., Jain, R., Stalcup, P.R. (2018). The Epidemiology and Medical Morbidity of Long-Distance Backpackers on the John Muir Trail in the Sierra Nevada. Wilderness \& Environmental Medicine, 29(2), 203-210

Statistics Canada. (2018). Canadians and the Outdoors: General Social Survey 
(Canadians at Work and Home).

Retrieved from

https://www150.statcan.gc.ca/n1/en/pub/ 11-627-m/11-627-m2018005-

eng.pdf?st=nKj80r92

Unite for Sight. (2015). Survey Methodologies.

Retrieved from

SurveyMonkey. (2020). SurveyMonkey - Get Started.

Retrieved from https://www.surveymonkey.com/?ut_sou rce=sem_Ip\&ut_source2=sem\&ut_sourc e3=header http://www.uniteforsight.org/globalhealth-university/survey-methodologies

USAID. (2011). The KAP Survey Model (Knowledge, Attitudes, and Practices). Retrieved from https://www.springnutrition.org/publications/toolsummaries/kap-survey-modelknowledge-attitudes-and-practices

Welch, T. (2000). Risk of giardiasis from consumption of wilderness water in North America: A systematic review of epidemiologic data. International Journal of Infectious Diseases, 4(2), 100-103 